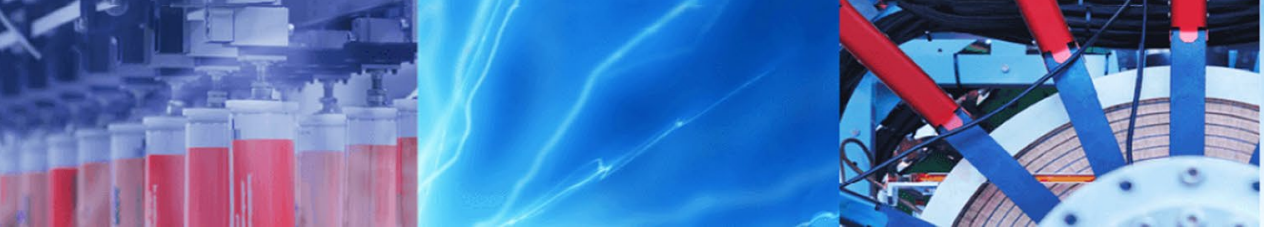

Research Article

\title{
Hydrogeochemistry and fluoride contamination in the hard rock terrain of central Telangana, India: analyses of its spatial distribution and health risk
}

\author{
Narsimha Adimalla ${ }^{1,2} \cdot$ Hui Qian ${ }^{1,2}$
}

(c) Springer Nature Switzerland AG 2019

\begin{abstract}
Groundwater is the primary source for drinking uses in the hard rock terrain of central Telangana, India, where most of the people rely on it for daily uses. Therefore, this study was carried out to comprehend the fluoride contamination and its associated health risk assessment to local dwellers. For this study, 54 groundwater samples were collected from bore wells and hand pumps in the study region and were analysed for fluoride and other physicochemical parameters. The results indicated by statistical mean values of $\mathrm{Na}^{+}, \mathrm{Ca}^{2+}, \mathrm{Mg}^{2+}$ and $\mathrm{K}^{+}$are 182.14, 59.79, 23.90 and 3.74 mg/L, respectively, while $\mathrm{HCO}_{3}{ }^{2-}, \mathrm{Cl}^{-}, \mathrm{SO}_{4}{ }^{2-}$ and $\mathrm{NO}_{3}{ }^{-}$are $236.1,230.8,167.7$ and $81.9 \mathrm{mg} / \mathrm{L}$, respectively. The fluoride concentration ranged from 0.8 to $4.2 \mathrm{mg} / \mathrm{L}$, with a mean of $2.21 \mathrm{mg} / \mathrm{L}$. Eighty-one percent of the groundwater samples exceeded the World Health Organization's water quality limit of $1.5 \mathrm{mg} / \mathrm{L}$ for fluoride. Piper trilinear diagram (PTD) signifies that groundwater quality in the study region is characterized by $\mathrm{Na}^{+}-\mathrm{Cl}^{-}, \mathrm{Ca}^{2+}-\mathrm{Mg}^{2+}-\mathrm{Cl}^{-}$and $\mathrm{Na}^{+}-\mathrm{HCO}_{3}^{-}-\mathrm{Cl}^{-}$hydrochemical water types. Gibbs diagrams indicate that all the major ion chemistry of the groundwater in the study region is controlled by rockwater interactions, while evaporation plays a minor role. The health risk assessment results revealed that the associated hazard quotient $(\mathrm{HQ})$ for the age range of 6 to 12 months within about $100 \%$ of the study area exceeded the acceptable $\mathrm{HQ}$ limits of 1 . Furthermore, the HQ for age categories 6-11 years, 11-16 years and 16-18 years within $96.2,68.5$ and $50 \%$, respectively, of the study locations were larger than 1. Results also indicate that age group 6 to 12 months was most prone to health risks in the study region. Therefore, in the study region, people should be taken necessary actions to abolish the groundwater contamination to protect the local dweller's health.
\end{abstract}

Keywords Fluoride contamination $\cdot$ Health risk assessment $\cdot$ Hard rock terrain · India

\section{Introduction}

Fluoride concentration in drinking water is one of the world issues; the presence of higher concentration of fluoride in drinking water always shows negative effects in human's health from many regions in the world [1-4]. Recent reports advocate that more than 200 million people from the 25 nations in the world are under the threat of the fluorosis problem [5-8]. Typically, the endemic fluorosis is more severe in parts of China [9-11], Turkey [12], Korea [13], Mexico [14], India [8, 15-22], Africa [23], Syria, Jordan, Ethiopia, Sudan, Tanzania, Kenya and Uganda [24-29]. Electronic supplementary material The online version of this article (https://doi.org/10.1007/s42452-019-0219-8) contains
supplementary material, which is available to authorized users.

\footnotetext{
$\triangle$ Narsimha Adimalla, adimallanarsimha@gmail.com | 'School of Environmental Science and Engineering, Chang'an University, No. 126 Yanta Road, Xi'an 710054, China. ${ }^{2}$ Key Laboratory of Subsurface Hydrology and Ecological Effects in Arid Region of the Ministry of Education, Chang'an University, No. 126 Yanta Road, Xi'an 710054, Shaanxi, China.
}

SN Applied Sciences (2019) 1:202 | https://doi.org/10.1007/s42452-019-0219-8

Received: 31 October 2018 / Accepted: 25 January 2019 / Published online: 2 February 2019 
The principal occurrence of fluoride in the groundwater is typically geogenic sources and also the contribution of anthropogenic (industries and agricultural fertilizers) sources is quite low [30-32]. The major fluoride-bearing minerals are apatite $\left[\mathrm{Ca}_{5}\left(\mathrm{PO}_{4}\right)_{3} \mathrm{~F}\right]$, fluorite $\left[\mathrm{CaF}_{2}\right]$, biotite $\left[\mathrm{K}(\mathrm{Mg}, \mathrm{Fe})_{3} \mathrm{AlSi}_{3} \mathrm{O} 10(\mathrm{~F}, \mathrm{OH})_{2}\right]$, hornblende $[(\mathrm{Ca}, \mathrm{Na})$ $\left.{ }_{2-3}(\mathrm{Mg}, \mathrm{Fe}, \mathrm{Al})_{5}(\mathrm{Al}, \mathrm{Si})_{8} \mathrm{O}_{22}(\mathrm{OH}, \mathrm{F})_{2}\right]$, muscovite, lepidolite, tourmaline, sphene, apophyllite, zinnwaldite, micas and amphiboles (where $\mathrm{F}^{-}$substitutes for $\mathrm{OH}^{-}$within the mineral structures), cryolite $\left(\mathrm{Na}_{3} \mathrm{AlF}_{6}\right)$, villiaumite $(\mathrm{NaF})$, topaz $\left(\mathrm{Al}_{2}\left(\mathrm{SiO}_{4}\right) \mathrm{F}_{2}\right)$ and soils that consist mainly of clay minerals such as vermiculite $\left[(\mathrm{MgFe}, \mathrm{Al})_{3}(\mathrm{Al}, \mathrm{Si})\right.$ $\left.{ }_{4} \mathrm{O}_{10}(\mathrm{OH})\right]$, kaolinite $\left[\mathrm{Al}_{2} \mathrm{Si}_{2} \mathrm{O}_{5}(\mathrm{OH})_{4}\right]$ and montmorillonite $\left[(\mathrm{Na}, \mathrm{Ca})_{0.33}(\mathrm{Al}, \mathrm{Mg})_{2}\left(\mathrm{Si}_{4} \mathrm{O}_{10}\right)(\mathrm{OH})_{2} \cdot \mathrm{nH}_{2} \mathrm{O}\right][10,33-36]$. Because of these mineral dissolutions in the groundwater through the various geochemical processes, the concentrations of fluoride may extremely increase.

In the Indian scenario, only four states were recognized with endemic fluorosis problem in the early 1930s; now it has reached to 21 states $[17,37]$. This shows that the problem of fluorosis was very aggravated within a short span of time in the many regions of India, and also it is a most alarming health concern in the country $[2,6,15,37$, 38]. Approximately more than 66 million people in India have been suffering from the deadly disease of fluorosis and all districts of Telangana state in India are reported an unacceptable range of fluoride concentration in drinking water $[38,39]$. In other words, the endemic fluorosis belt (EFB, Telangana state in India) has also evidenced that more populace suffers from the various health risks due to the intake of highly fluoride-contaminated drinking water. Therefore, many groundwater scientists and researchers have adopted the human health risk assessment model to delineate the adverse effect of ingesting fluoride-contaminated water; Adimalla and Li [18] studied on groundwater quality and potential health risks from fluoride content in drinking water in the rock-dominant semi-arid region of Telangana and found that children are more adversely affected by health risks due to intake of elevated fluoride concentration in drinking water. Similar results were reported in various regions from FEB such as Nirmal province [16] and semi-arid region of Medak [2, $37,40]$. This shows a few studies were focused in parts of EFD, but no previous investigation in the hard rock terrain of central Telangana, India, in this regard. This shows a large scientific gap between fluoride contamination and its potential health risk evaluation in the hard rock terrain of central Telangana, India.

The main objective of the present study was to identify the fluoride-vulnerable zones using a spatial distribution map of fluoride and to assess the human health risk associated with fluoride concentration in the groundwater of the study. To accomplish this, ingestion and dermal pathways were computed in seven age groups: $6-12$ months, 6-11 years, 11-16 years, 16-18 years, 18-21 years, $\geq 21$ years and $>65$ years. The outcome of this study will be helpful to policy and decision makers to take suitable and significant measures that can improve the quality of life in the study region.

\section{Study area}

The study area is located in the central part of Telangana state, India (Fig. 1), which also is situated about $105 \mathrm{~km}$ north of Hyderabad on Hyderabad-Karimnagar highway, and it is bounded by longitude 78.76942 to $78.90232 \mathrm{E}$ and latitude 18.06768 to $18.24402 \mathrm{~N}$ [41]. The climate is semiarid, with a mean annual temperature of $25^{\circ} \mathrm{C}$ in winter and of $48^{\circ} \mathrm{C}$ in summer [41]. The mean annual rainfall is recorded as $745 \mathrm{~mm}$, and a major portion of the rainfall is received from the southwest monsoon period (June-September). The study area is totally occupied by granite rocks of Archaean age [41]. In the study region, groundwater occurs under phreatic conditions, but it is desaturated and under semi-confined conditions in the fractured zones. The depth of weathering varies from 5.5 to $15 \mathrm{~m}$ below the ground level. The fracture zones are mostly confined up to 75 to $100 \mathrm{~m}$ below the ground level. However, the depth of bore wells ranges from 20 to $30 \mathrm{~m}$ in the study region, and groundwater extraction from bore wells are estimated to be 0.17 to $0.3 \mathrm{~L} / \mathrm{s}$ [41].

\section{Materials and methods}

\subsection{Sample collection and analysis}

Groundwater samples $(N=54)$ were collected from hand pumps/bore well in the study region during November 2016. Prior to sampling, each pump/bore well was pumped for more than $10 \mathrm{~min}$ to tap aquifer water. The groundwater samples were collected in 1-L high-density polyethylene (HDP) bottles. The HDP bottles were first rinsed more than three times with groundwater and then completely filled and sealed with caps and then stored at $4{ }^{\circ} \mathrm{C}[42]$.

The water samples were analysed for various hydrochemical parameters such as $\mathrm{pH}$, electrical conductivity (EC), total dissolved solids (TDS), total hardness (TH) as $\mathrm{CaCO}_{3}$, calcium $\left(\mathrm{Ca}^{2+}\right)$, sodium $\left(\mathrm{Na}^{+}\right)$, potassium $\left(\mathrm{K}^{+}\right)$, chloride $\left(\mathrm{Cl}^{-}\right)$, bicarbonate $\left(\mathrm{HCO}_{3}{ }^{-}\right)$, sulphate $\left(\mathrm{SO}_{4}{ }^{2-}\right)$, nitrate $\left(\mathrm{NO}_{3}{ }^{-}\right)$and fluoride $\left(\mathrm{F}^{-}\right)$. The in situ parameters such as hydrogen ion concentration $(\mathrm{pH}), \mathrm{EC}$ and TDS were measured at each sampling site with the help of a portable $\mathrm{pH} /$ EC/TDS meter (Hanna instrument: HI 9811-5) which was 


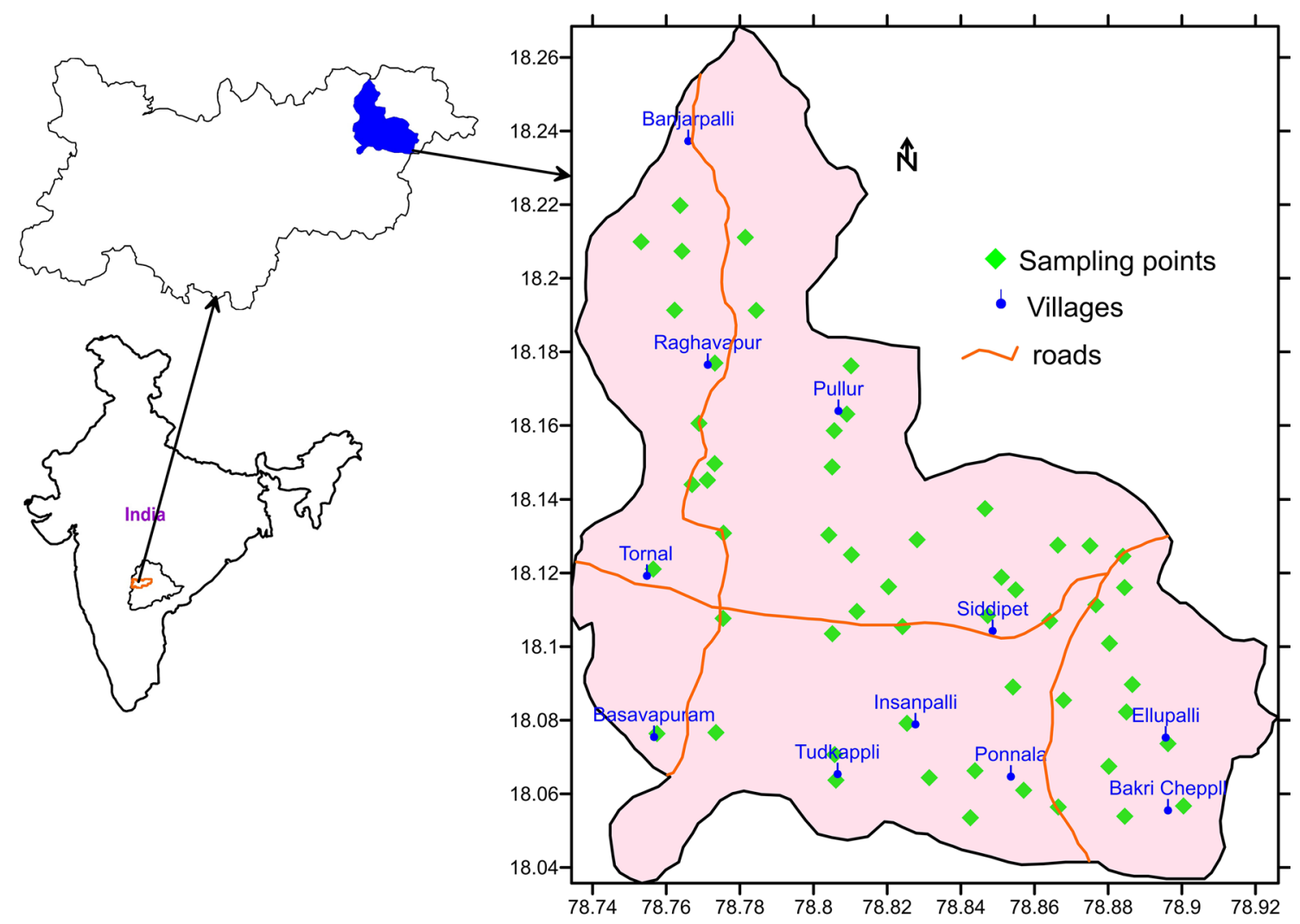

Fig. 1 Map of study area showing the sampling locations

calibrated every day before use. Chloride was measured by $\mathrm{AgNO}_{3}$ titration method; $\mathrm{HCO}_{3}{ }^{-}$was measured using an acid titration method; $\mathrm{Ca}^{2+}, \mathrm{Mg}^{2+}$ and $\mathrm{TH}$ were analysed using titration with ethylenediaminetetraaceticacid (EDTA). $\mathrm{Na}^{+}$and $\mathrm{K}^{+}$were measured using a flame photometer (Model 130 Systronics); $\mathrm{SO}_{4}{ }^{2-}$ and $\mathrm{NO}_{3}{ }^{-}$was measured by $\mathrm{BaCl}_{2}$ turbidity method using a UV-visible spectrophotometer; fluoride concentration in groundwater was determined by using ion-selective electrode method [42]. As per experimental requirement, $2 \mathrm{~mL}$ of total ionic strength adjusting buffer grade III (TISAB III) was added in $20 \mathrm{~mL}$ of sample. The ion meter was calibrated for a slop of $-59.2 \pm 2$ $[38,42]$.

\subsection{Quality of chemical data}

The accuracy of the analytical results was cross-checked by calculating ionic balance error (IBE) as follows:

$\mathrm{IBE}=\frac{\sum \text { Cations }-\sum \text { Anions }}{\sum \text { Cations }+\sum \text { Anions }} \times 100$

where all cations and anions are expressed in meq/L. The computed IBE was within the acceptable limit of $\pm 10 \%$ [43].

\subsection{Health risk assessment model}

Health risk assessment has widely been used in research associated with human health $[18,20,40]$. Typically, intake of contaminated drinking water may pose health risks to humans. Therefore, it is very essential to understand the degree of potential health risks for different age groups in the study region. The United States Environmental Protection Agency $[44,45]$ introduced a health risk assessment model which is being used to evaluate the vulnerable age groups after being exposed to a certain harmful chemical through different pathways. In the present study, drinking water ingestion and dermal pathways were given primary priority to estimate the potential human health risks for seven different age groups (6-12 months, 6-11 years, 11-16 years, $16-18$ years, $18-21$ years, $\geq 21$ years and $>65$ years) [44]. In the study region, populace was majorly exposed to elevated fluoride through ingestion/drinking and dermal contacts. However, inhalation is not considered as a principal exposure route for fluoride in the study region. Chronic daily dose and hazard quotient of fluoride via ingestion and dermal were computed using the following equations:

$\mathrm{CDD}_{\text {in }}=\frac{C_{\mathrm{fw}} \times \mathrm{IR}_{\mathrm{w}} \times \mathrm{EF}_{\mathrm{r}} \times \mathrm{ED}}{\mathrm{BW} \times \mathrm{AT}}$ 
$\mathrm{CDD}_{\mathrm{de}}=\frac{\mathrm{C}_{\mathrm{fw}} \times \mathrm{ESA} \times K \times \mathrm{EF}_{\mathrm{r}} \times \mathrm{ED} \times \mathrm{CF}}{\mathrm{BW} \times \mathrm{AT}}$

$H Q_{i n}=\frac{C D D_{\text {in }}}{R f D}$

$\mathrm{HQ}_{\mathrm{de}}=\frac{\mathrm{CDD}_{\mathrm{de}}}{\mathrm{RfD}}$

where $\mathrm{CDD}_{\text {in }}$ : chronic daily dose via ingestion ( $\mathrm{mg} / \mathrm{kg}$ day), $\mathrm{CDD}_{\mathrm{de}}$ : chronic daily dose via dermal exposure route $(\mathrm{mg} /$ $\mathrm{kg}$ day), $C_{\mathrm{fw}}$ : concentration of fluoride in drinking water (mg/L), $\mathrm{EF}_{\mathrm{r}}$ : exposure frequency (days/years), ED: exposure duration (years), BW: body weight ( $\mathrm{kg})$, AT: resident time (days/years), ESA: exposed skin area $\left(\mathrm{cm}^{2}\right), K$ : skin adherence factor, $\mathrm{CF}$ : conversion factor $\left(\mathrm{L} / \mathrm{cm}^{3}\right), \mathrm{RfD}$ : reference dose of fluoride $(0.06 \mathrm{mg} / \mathrm{kg}$ day) obtained from the Integrated Risk Information System (IRIS) and database of the US EPA $[44,45]$. Furthermore, the detailed reference values of each parameter used for the above calculation are presented in Table $1[1,2,10,16,18,40,44,45]$.

\section{Result and discussion}

The characteristics of groundwater samples are shown in Supplementary Table S1. Groundwater of the study region displayed neutral-to-mildly alkaline nature, and $\mathrm{pH}$ differed from 6.82 to 8.78 with a mean value of 7.56 . EC is largely variable ranging from 169 to $1535 \mu \mathrm{S} / \mathrm{cm}$ with an average of $750.67 \mu \mathrm{S} / \mathrm{cm}$. TDS values varied from
108 to $983 \mathrm{mg} / \mathrm{L}$ with a mean of $480.43 \mathrm{mg} / \mathrm{L}$, while $\mathrm{TH}$ values ranged from 125 to $575 \mathrm{mg} / \mathrm{L}$ with an average of $245.37 \mathrm{mg} / \mathrm{L}$. Among the cations, the concentrations of $\mathrm{Na}^{+}, \mathrm{Ca}^{2+}, \mathrm{Mg}^{2+}$ and $\mathrm{K}^{+}$ions differed from 38 to $440 \mathrm{mg} / \mathrm{L}$, 16 to $100 \mathrm{mg} / \mathrm{L}, 2$ to $103 \mathrm{mg} / \mathrm{L}$ and 1 to $24 \mathrm{mg} / \mathrm{L}$ with mean values of $182.14,59.79,23.90$ and $3.74 \mathrm{mg} / \mathrm{L}$, respectively (Table S1). However, among the anions, the concentrations of $\mathrm{HCO}_{3}{ }^{2-}, \mathrm{Cl}^{-}, \mathrm{SO}_{4}{ }^{2-}, \mathrm{NO}_{3}{ }^{-}$and $\mathrm{F}^{-}$ions ranged from 100 to $390 \mathrm{mg} / \mathrm{L}, 43$ to $756 \mathrm{mg} / \mathrm{L}, 96$ to $278 \mathrm{mg} / \mathrm{L}, 6.6$ to $280 \mathrm{mg} / \mathrm{L}$ and 0.8 to $4.2 \mathrm{mg} / \mathrm{L}$, respectively (Table S1). Therefore, the mean cation and anion concentrations followed a decreasing order of $\mathrm{Na}^{+}>\mathrm{Ca}^{2+}>\mathrm{Mg}^{2+}>\mathrm{K}^{+}$and $\mathrm{HCO}_{3}{ }^{-}>\mathrm{Cl}^{-}>\mathrm{SO}_{4}{ }^{2-}>\mathrm{NO}_{3}{ }^{-}>\mathrm{F}^{-}$, respectively.

The fluoride concentration in groundwater samples ranged from 0.8 to $4.2 \mathrm{mg} / \mathrm{L}$ with an average value of $2.21 \mathrm{mg} / \mathrm{L}$. Of the groundwater samples, $81 \%$ showed fluoride concentration higher than the World Health Organization (WHO) prescribed limit of $1.5 \mathrm{mg} / \mathrm{L}$ for drinking purposes [46]. Edmunds and Smedley [47] stated that the optimal range of fluoride in drinking water is $1 \mathrm{mg} / \mathrm{L}$, and the study region groundwater samples were classified into three groups: low fluoride $(<1 \mathrm{mg} / \mathrm{L})$, acceptable range (1 to $1.5 \mathrm{mg} / \mathrm{L}$ ) and high $(1.5 \mathrm{mg} / \mathrm{L})$, respectively (Table 2 ). As shown in Table 2, 17\% showed fluoride concentration acceptable range ( 1 to $1.5 \mathrm{mg} / \mathrm{L}$ ) belong to group-I, and $81 \%$ of groundwater samples locked in group-II, which were not suitable for drinking purposes. Adimalla et al. [17] studied the controlling factors of fluoride in groundwater of Peddavagu in central Telangana (PCT), India, and found higher fluoride concentration in the range of 0.6 to $3.6 \mathrm{mg} / \mathrm{L}$. They also stated that rock-water interaction,

Table 1 Key parameters for computing the exposure risk of fluoride through ingestion and dermal pathways

\begin{tabular}{|c|c|c|c|c|c|c|c|c|}
\hline Parameters & Unit & 6-12 months & $6-11$ years & $11-16$ years & 16-18 years & $18-21$ years & $\geq 21$ years & $>65$ years \\
\hline \multicolumn{9}{|l|}{ Ingestion pathway } \\
\hline Ingestion rate $\left(\mathrm{IR}_{\mathrm{w}}\right)$ & L/day & 1 & 1.32 & 1.82 & 1.78 & 2.34 & 2.94 & 2.73 \\
\hline Exposure frequency $\left(\mathrm{EF}_{\mathrm{r}}\right)$ & Days/year & 365 & 365 & 365 & 365 & 365 & 365 & 365 \\
\hline Exposure duration (ED) & Year & 6 & 6 & 6 & 6 & 30 & 30 & 30 \\
\hline Body weight (BW) & $\mathrm{kg}$ & 9.1 & 29.3 & 54.2 & 67.6 & 67.6 & 78.8 & 80 \\
\hline Average time $\left(\mathrm{AT}_{\mathrm{r}}\right)$ & Days & 2190 & 2190 & 2190 & 2190 & 10,950 & 10,950 & 10,950 \\
\hline Concentration of element $\left(C_{\mathrm{fw}}\right)$ & $\mathrm{mg} / \mathrm{L}$ & & & Present study & & & & \\
\hline \multicolumn{9}{|l|}{ Dermal pathway } \\
\hline Skin surface area (SA) & $\mathrm{cm}^{2}$ & 4500 & 10,500 & 15,700 & 18,000 & 19,550 & 19,800 & 19,400 \\
\hline Exposure time (ET) & $\mathrm{h} / \mathrm{event}$ & 0.54 & 0.54 & 0.54 & 0.54 & 0.71 & 0.71 & 0.71 \\
\hline Exposure frequency $\left(\mathrm{EF}_{\mathrm{r}}\right)$ & Days/year & 350 & 350 & 350 & 350 & 350 & 350 & 350 \\
\hline Exposure duration (ED) & Year & 6 & 6 & 6 & 6 & 30 & 30 & 30 \\
\hline Conversion factor (CF) & $\mathrm{L} / \mathrm{cm}^{3}$ & 0.001 & 0.001 & 0.001 & 0.001 & 0.001 & 0.001 & 0.001 \\
\hline Body weight (BW) & $\mathrm{kg}$ & 9.1 & 29.3 & 54.2 & 67.6 & 67.6 & 78.8 & 80 \\
\hline Average time $\left(A T_{r}\right)$ & Days & 2190 & 2190 & 2190 & 2190 & 10,950 & 10,950 & 10,950 \\
\hline Skin adherence factor $\left(K_{p}\right)$ & $\mathrm{cm} / \mathrm{h}$ & 0.001 & 0.001 & 0.001 & 0.001 & 0.001 & 0.001 & 0.001 \\
\hline Concentration of element $\left(C_{f w}\right)$ & $\mathrm{mg} / \mathrm{L}$ & & & Present study & & & & \\
\hline
\end{tabular}




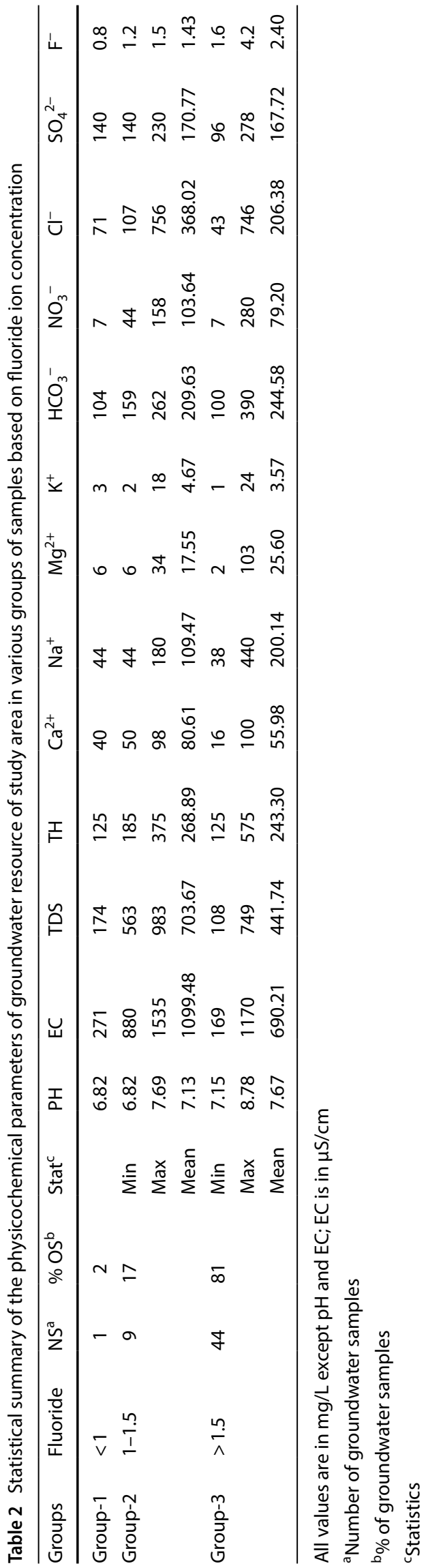

and fluoride-rich minerals play major role to elevate the fluoride content in the groundwater of the PCT, India. Narsimha and Sudarshan [7] conducted an investigation on fluoride contamination in groundwater from Basara, Telangana. They reported that the fluoride concentration differed from 0.06 to $4.33 \mathrm{mg} / \mathrm{L}$, due to weathering of rocks, and mineral dissolution was the principal factor, which enhanced the fluoride content in groundwater of the study region. However, in the study region, anthropogenic activity is much negligible; therefore, higher fluoride content in groundwater could be due to geogenic sources $[2,7,8,10,38-40]$.

\subsection{Chemical weathering}

Gibbs [48] stated that evaporation and water-rock interaction or rock dominance are the major mechanisms controlling the world water chemistry besides atmospheric precipitation. Gibbs plots, TDS versus $\left(\mathrm{Na}^{+}+\mathrm{K}^{+}\right) /\left(\mathrm{Na}^{+}+\mathrm{K}^{+}+\mathrm{Ca}^{2+}\right)$ for cations and TDS versus $\mathrm{Cl}^{-} / \mathrm{Cl}^{-}+\mathrm{HCO}_{3}{ }^{-}$for anions were plotted (Fig. 2) in order to demonstrate the groundwater evolution process and impact of country rock groundwater chemistry. As shown in Fig. 2, high-fluoride-content samples are found in rock dominance and slightly inclined towards evaporation dominance field, indicating that the mechanism of rock dominance plays a significant role in controlling the groundwater chemistry, which also enhances the fluoride content in groundwater of the hard rock terrain of the study region, India. $[8,17,18,38,39]$ denoted that rock-water interaction typically occurs in the regions occupied by the hard rocks, and low rainfall and high temperature could lead to the high rate of residence time/slow percolation of water through pore spaces, which intensely enhance the ions concentration in groundwater. Furthermore, the molar ratio of $\mathrm{Ca}^{2+} / \mathrm{Na}^{+}$versus $\mathrm{Mg}^{2+} / \mathrm{Na}^{+}$plot (Fig. 3), indicating a high number of groundwater samples are affected by silicate weathering and a few are evaporate dissolution in the study region. Further, the molar ratio of $\mathrm{Na}^{+} / \mathrm{Cl}^{-}$ranged from 0.13 to 13.75 with a mean value of $2.09,57 \%$ of groundwater samples have larger than 1 , indicating that silicate weathering is the principal process responsible for the excess release of $\mathrm{Na}^{+}$into the groundwater $[2,8,10,49]$.

\subsection{The dominant water types}

The Piper trilinear diagram (PTD) is very worthwhile for assessing the geochemical evolution of groundwater chemistry and to identify the dominant water types [50]. Essentially, PTD consists of two triangular fields and one diamond field (Fig. 4). As shown in Fig. 4, anions ( $\mathrm{Ca}^{2+}$, $\mathrm{Mg}^{2+}$ and $\left.\mathrm{Na}^{+}+\mathrm{K}^{+}\right)$and cations $\left(\mathrm{Cl}^{-}, \mathrm{SO}_{4}{ }^{2-}\right.$ and $\left.\mathrm{HCO}_{3}{ }^{-}\right)$are 

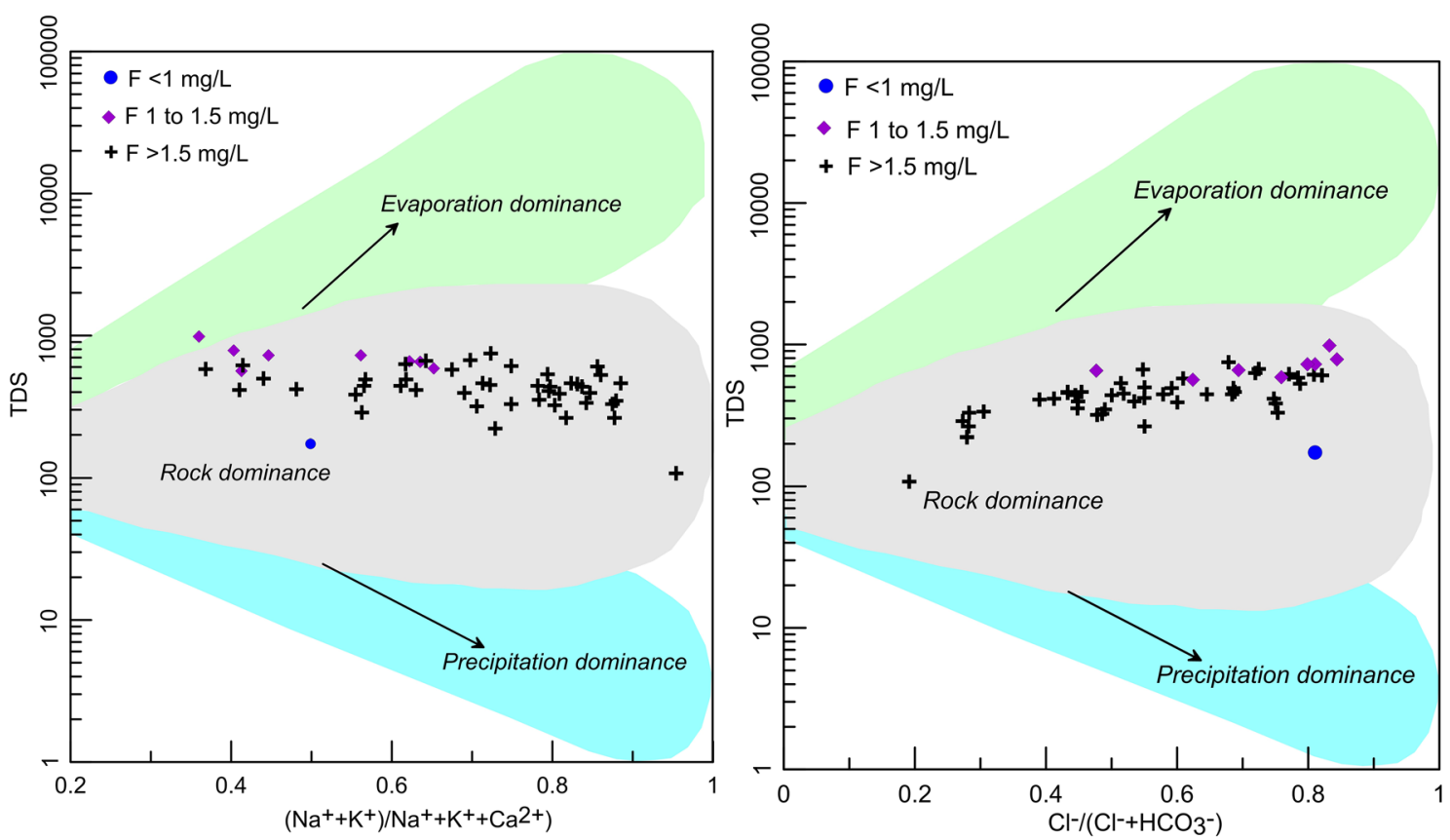

Fig. 2 Gibbs plot for the groundwater samples collected from the study region

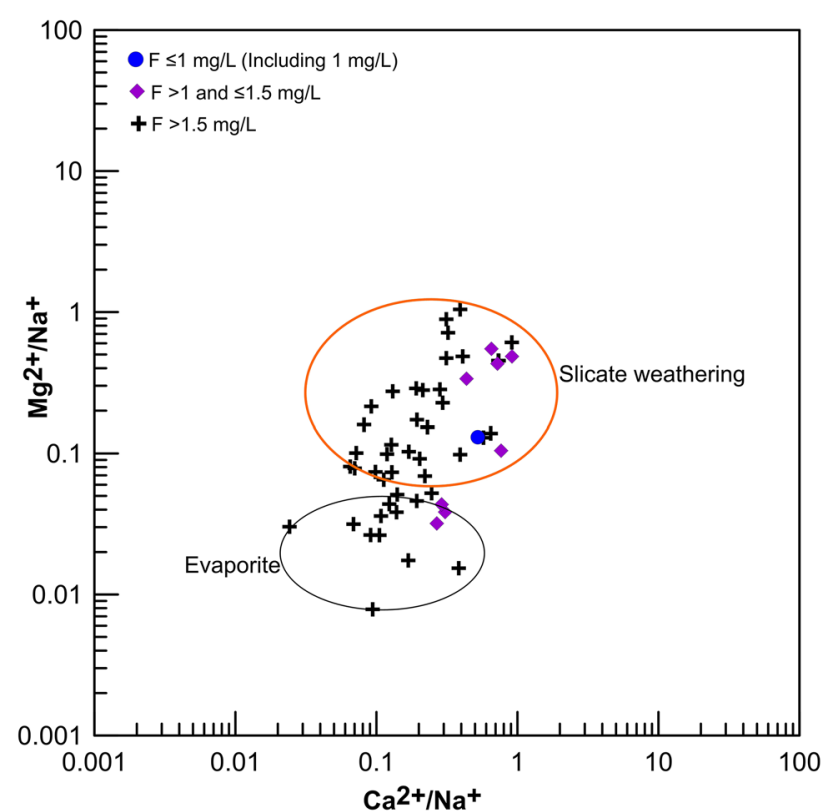

Fig. 3 Scatter plot between $\mathrm{Ca}^{2+} / \mathrm{Na}^{+}$versus $\mathrm{Mg}^{2+} / \mathrm{Na}^{+}$

projected into a central diamond-shaped field representing the nine characteristics of water which are depicted in Fig. 4. In the study region, $74 \%$ of groundwater samples show alkaline earth metals $\left(\mathrm{Ca}^{2+}+\mathrm{Mg}^{2+}\right)$ exceeding alkali metal cation $\left(\mathrm{Na}^{+}+\mathrm{K}^{+}\right)$, in which plotted points fall in zone 1 , while $76 \%$ of samples fall in zone 4 , indicating weak acids $\left(\mathrm{HCO}_{3}{ }^{-}+\mathrm{CO}_{3}{ }^{2-}\right)$ over strong acids $\left(\mathrm{SO}_{4}{ }^{2-}+\mathrm{Cl}^{-}\right)$.
Furthermore, $59 \%$ and $41 \%$ of groundwater samples fall in the zone 9 and zone 7 , signifying that no dominant cation-anion exchange and non-carbonate alkali exceed (Fig. 4). Based on the cation and anions contribution in the study region groundwater, three principal, dominant hydrochemical water types are found which are of $52 \%$ of $\mathrm{Na}^{+}-\mathrm{Cl}^{-}, 25 \%$ of $\mathrm{Ca}^{2+}-\mathrm{Mg}^{2+}-\mathrm{Cl}^{-}$and $21 \%$ of $\mathrm{Na}^{+}-\mathrm{HCO}_{3}{ }^{-}-\mathrm{Cl}^{-}$(Fig. 4).

Typically, high-fluoride groundwater majorly belongs to $\mathrm{Na}^{+}-\mathrm{HCO}_{3}{ }^{-}$hydrochemical type in the hard terrain of the world $[2,7,10,18,38,39]$, while only $2 \%$ of $\mathrm{Na}^{+}-\mathrm{HCO}_{3}{ }^{-}$hydrochemical type were found in the study region groundwater. Interestingly, high-fluoride groundwater belongs to $\mathrm{Na}^{+}-\mathrm{Cl}^{-}-, \mathrm{Ca}^{2+}-\mathrm{Mg}^{2+}-\mathrm{Cl}^{-}$- and $\mathrm{Na}^{+}-\mathrm{HCO}_{3}{ }^{-}-\mathrm{Cl}^{-}$-type waters. These water had high EC $(1535 \mu \mathrm{S} / \mathrm{cm})$ and high TDS (983 mg/L), suggesting a major role of water-rock interaction and long residence time [47, 51-53].

\subsection{Detecting ion exchange by hydrogeochemical analysis}

Ion exchange typically occurs between groundwater and aquifers material which plays a major role in groundwater chemistry and also provide quantitative information about direct and reverse ion exchange process in the studied groundwater. Chloro-alkaline indices (CAI) were proposed by [54]; CAI-II and CAI-II were computed using the following equations, where all ions were expressed in meq/L. 


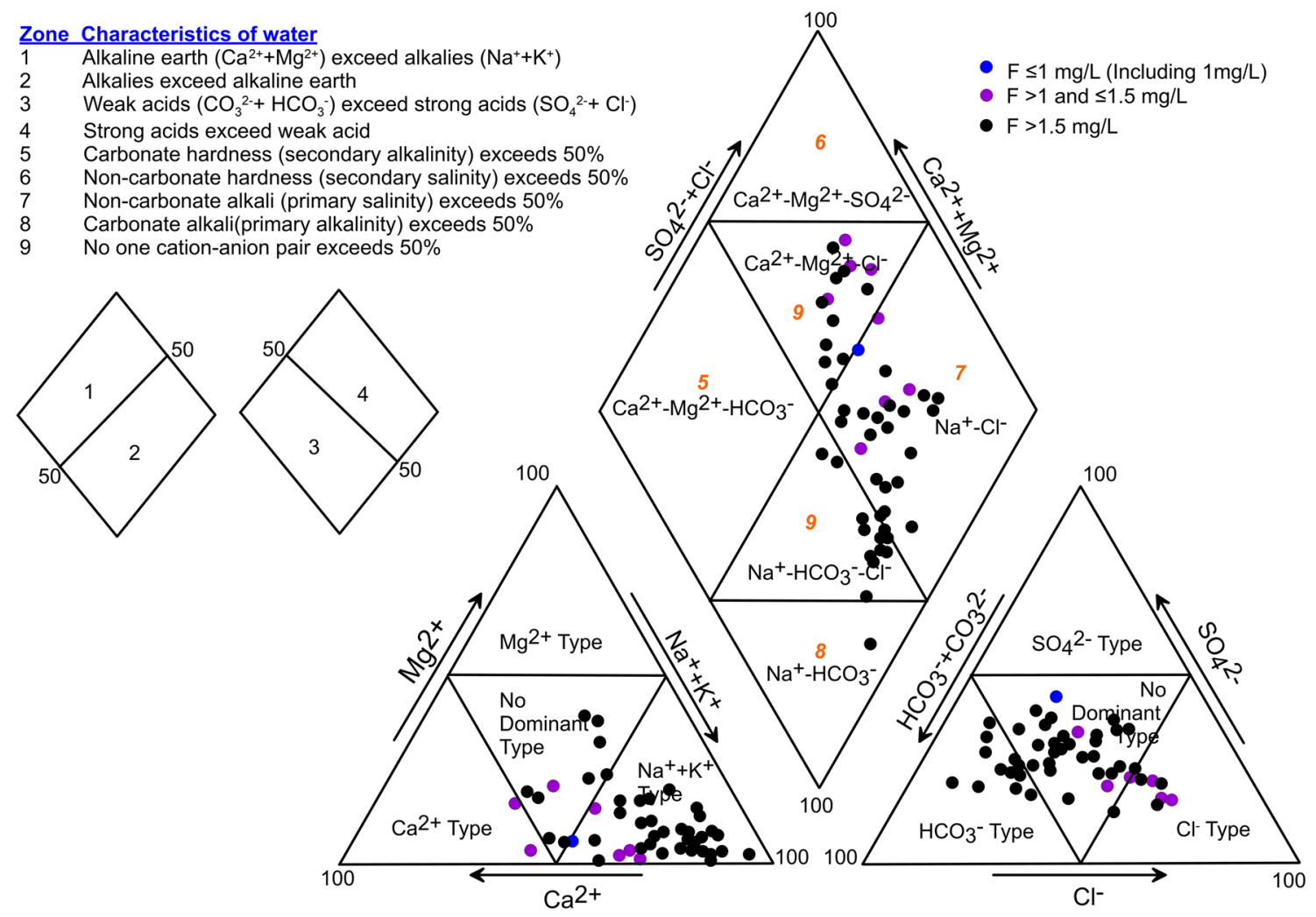

Fig. 4 Characterization of hydrochemical facies with piper plot

$\mathrm{CAI}-\mathrm{I}=\frac{\mathrm{Cl}-\left(\mathrm{Na}^{+}+\mathrm{K}^{+}\right)}{\mathrm{Cl}^{-}}$

CAI-II $=\frac{\mathrm{Cl}-\left(\mathrm{Na}^{+}+\mathrm{K}^{+}\right)}{\left(\mathrm{SO}_{4}^{2-}+\mathrm{HCO}_{3}^{-}+\mathrm{CO}_{3}^{2-}+\mathrm{NO}_{3}^{-}\right)}$

When reverse ion exchange occurs between $\mathrm{Na}^{+}$and $\mathrm{K}^{+}$ in the aquifer material with $\mathrm{Mg}^{2+}$ and $\mathrm{Ca}^{2+}$ in the groundwater, then these two indices will be negative and the concentrations of $\mathrm{Na}^{+}$and $\mathrm{K}^{+}$in water will also increase. On the other hand, if direct ion exchange happens between $\mathrm{Na}^{+}$ and $\mathrm{K}^{+}$in the groundwater with $\mathrm{Mg}^{2+}$ and $\mathrm{Ca}^{2+}$ attached to aquifer material, both of the above (CAI-I and CAI-II) indices will be positive and the concentrations of $\mathrm{Mg}^{2+}$ and $\mathrm{Ca}^{2+}$ will increase in the groundwater [54]. The CAl-I and $\mathrm{CAl}-\mathrm{II}$ of the study region groundwater ranged from -12.79 to 0.87 and -2.11 to 1.99 , respectively. Furthermore, the obtained results are plotted in bar diagram (Fig. 5) and show that the reverse ion exchange occurs for about $57.4 \%$ of the study region groundwater samples since both CAI-I and CAI-II indices are negative. On the other hand, the direct ion exchange is dominant for about $42.6 \%$ of the total groundwater samples of the hard rock region of India.

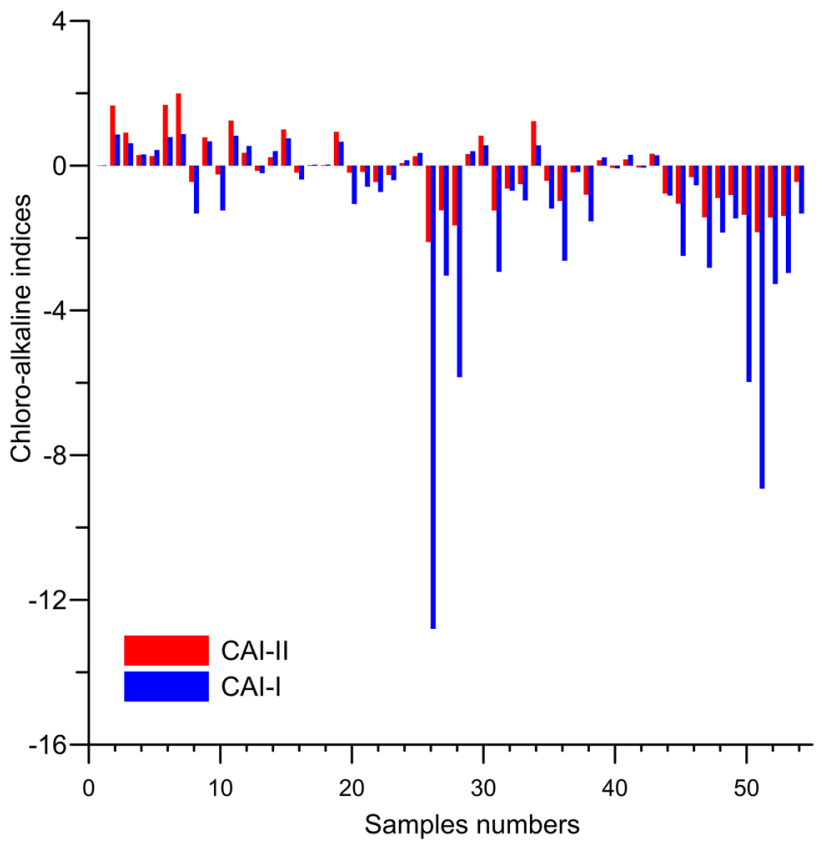

Fig. 5 Bar diagram of the chloro-alkaline indices (CAI-I and CAI-II) for the groundwater samples of the study region 


\subsection{Spatial distribution of fluoride}

The base map was prepared using Toposheet No. 56J/16 on 1:50,000 scale. Their spatial attributes were added and analysed in "Surfer 15 software" environment (Golden Software, USA). Ordinary kriging interpolation method (Surfer 15 software) was used to generate the spatial distribution pattern of the fluoride in the groundwater of the study region. Spatial distribution of fluoride in groundwater of the study region is depicted in Fig. 6 . The spatial variation map of fluoride shows that larger than $3 \mathrm{mg} / \mathrm{L}$ fluoride concentration was noticed in the villages of Tudkapalli, Ponnala and Bakri Cheppll which are the southern part of the study area (Fig. 6). Furthermore, Tornal, Basavapuram, Siddipet, Insanpalli and Ellupalli villages groundwater also have a higher range of fluoride content ( 1.5 to $3 \mathrm{mg} / \mathrm{L}$ ), indicating water is unsuitable for drinking uses in the study region (Fig. 6). Only a few villages (Raghavapur, Pullur and Banjarpalli) are in the safe zone with respect to fluoride concentration in the groundwater of the entire study region.

\subsection{Fluoride health risk assessment}

The health risk assessment model obtained from US EPA $[44,45]$ is used to calculate the non-carcinogenic effects to different age groups such as 6-12 months, 6-11 years, 11-16 years, $16-18$ years, $18-21$ years, $\geq 21$ years and

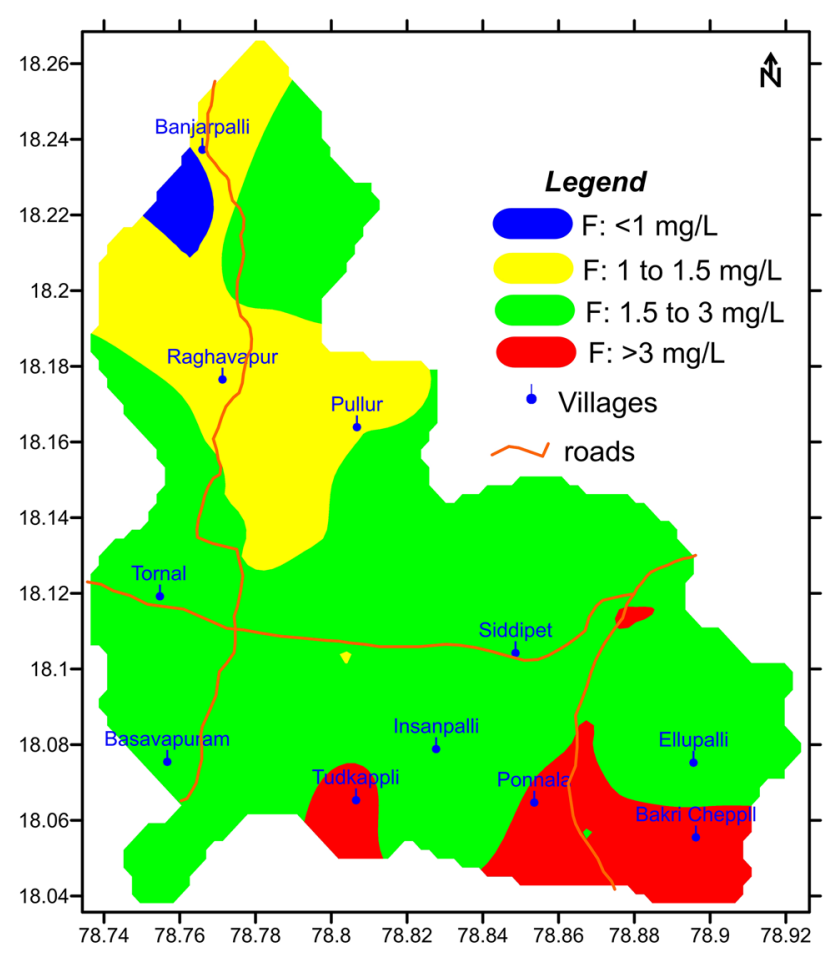

Fig. 6 Spatial distribution map of fluoride in the study region
$>65$ years who consume groundwater as their daily drinking and bath water sources. A succession of human health risks for dissimilar age groups people are computed, integrating the above-mentioned parameters as well as concentrations of fluoride in groundwater using HQs.

\subsubsection{Ingestion pathway}

The hazard quotient ingestion $\left(\mathrm{HQ}_{\text {in }}\right)$ associated with fluoride concentration on different age classification (6-12 months, 6-11 years, $11-16$ years, $16-18$ years, $18-21$ years, $\geq 21$ years and $>65$ years) was estimated, integrating the indicators obtained from the US EPA Exposure Factor Handbook (US EPA [44]) as well as the fluoride concentration in the groundwater from the hard rock terrain of central Telangana, India.

The $H Q_{\text {in }}$ values ranged from 1.465 to 7.692 with a mean of 4.043 for age 6 to 12 months. The $\mathrm{HQ}_{\text {in }}$ values for age 6 to 11 years varied from 0.601 to 3.154 with an average value of 1.657 . The values for age 11 to 16 years, 16 to 18 years, 18 to 21 years, $>21$ years and $>65$ years range from 0.448 to $2.351,0.394$ to $2.071,0.462$ to $2.423,0.497$ to 2.612 and 0.455 to 2.389 with a mean values of 1.235 , $1.088,1.274,1.373$ and 1.255 , respectively (Table 3 ). In the study region, the obtained results of $\mathrm{HQ}_{\mathrm{in}}$ shown that all the locations were above the acceptable limits $\mathrm{HQ}=1$ for age 6 to 12 months group, while $96.2,68.5$ and $50 \%$ of the samples locations were also larger than the acceptable limits for 6- to 11-year, 11- to 16-year and 16- to 18-year age groups, respectively. The abundance of mean vulnerable age groups is in descending order of 6 to 12 months $>6$ to 11 years $>21$ years $>65$ years $>18$ to 21 years $>11$ to 16 years $>16$ to 18 years. Interestingly, non-carcinogenic health risk results indicated that the 6- to 12-month age groups were more likely to suffer from health complications associated with consumptions of water laden with a larger concentration of fluoride in the study region drinking water. The health risk to 6- to 12-month age group is $3.22,2.94$, and 3.17 times of that to $>65$ years, $>21$ years and 18- to 21-year age groups because of the discrepancy of exposure parameters. It is obvious that the 6- to 12-month age group undertake higher health risk than other six age groups in the hard rock terrain of central Telangana, India. Conclusively, the $\mathrm{HQ}_{\text {in }}$ values obtained in this study should serve as baseline information for water management authorities, policymakers and the society at large towards addressing these pollution issues.

\subsubsection{Dermal contact pathway}

The results of the dermal hazard quotient $\left(\mathrm{HQ}_{\mathrm{de}}\right)$ for different age groups are presented in Table S2. The results of $\mathrm{HQ}_{\mathrm{de}}$ show that the health risk ranged from $9.78 \mathrm{E}-04$ to 
Table 3 Hazard quotients via ingestion pathway for different age classification

\begin{tabular}{|c|c|c|c|c|c|c|c|}
\hline S. no. & 6 to 12 months & 6 to 11 years & 11 to 16 years & 16 to 18 years & 18 to 21 years & $>21$ years & $>65$ years \\
\hline CTI-1 & 1.465 & 0.601 & 0.448 & 0.394 & 0.462 & 0.497 & 0.455 \\
\hline CTI-2 & 2.198 & 0.901 & 0.672 & 0.592 & 0.692 & 0.746 & 0.683 \\
\hline CTI-3 & 2.564 & 1.051 & 0.784 & 0.690 & 0.808 & 0.871 & 0.796 \\
\hline CTI-4 & 2.564 & 1.051 & 0.784 & 0.690 & 0.808 & 0.871 & 0.796 \\
\hline CTI-5 & 2.564 & 1.051 & 0.784 & 0.690 & 0.808 & 0.871 & 0.796 \\
\hline CTI-6 & 2.747 & 1.126 & 0.839 & 0.740 & 0.865 & 0.933 & 0.853 \\
\hline CTI-7 & 2.747 & 1.126 & 0.839 & 0.740 & 0.865 & 0.933 & 0.853 \\
\hline CTI-8 & 2.747 & 1.126 & 0.839 & 0.740 & 0.865 & 0.933 & 0.853 \\
\hline CTI-9 & 2.930 & 1.201 & 0.895 & 0.789 & 0.923 & 0.995 & 0.910 \\
\hline CTI-10 & 2.930 & 1.201 & 0.895 & 0.789 & 0.923 & 0.995 & 0.910 \\
\hline CTI-11 & 2.930 & 1.201 & 0.895 & 0.789 & 0.923 & 0.995 & 0.910 \\
\hline CTI-12 & 2.930 & 1.201 & 0.895 & 0.789 & 0.923 & 0.995 & 0.910 \\
\hline CTI-13 & 3.114 & 1.276 & 0.951 & 0.838 & 0.981 & 1.057 & 0.967 \\
\hline CTI-14 & 3.114 & 1.276 & 0.951 & 0.838 & 0.981 & 1.057 & 0.967 \\
\hline CTI-15 & 3.114 & 1.276 & 0.951 & 0.838 & 0.981 & 1.057 & 0.967 \\
\hline CTI-16 & 3.297 & 1.352 & 1.007 & 0.888 & 1.038 & 1.119 & 1.024 \\
\hline CTI-17 & 3.297 & 1.352 & 1.007 & 0.888 & 1.038 & 1.119 & 1.024 \\
\hline CTI-18 & 3.297 & 1.352 & 1.007 & 0.888 & 1.038 & 1.119 & 1.024 \\
\hline CTI-19 & 3.480 & 1.427 & 1.063 & 0.937 & 1.096 & 1.181 & 1.081 \\
\hline CTI-20 & 3.480 & 1.427 & 1.063 & 0.937 & 1.096 & 1.181 & 1.081 \\
\hline CTI-21 & 3.480 & 1.427 & 1.063 & 0.937 & 1.096 & 1.181 & 1.081 \\
\hline CTI-22 & 3.480 & 1.427 & 1.063 & 0.937 & 1.096 & 1.181 & 1.081 \\
\hline CTI-23 & 3.480 & 1.427 & 1.063 & 0.937 & 1.096 & 1.181 & 1.081 \\
\hline CTI-24 & 3.480 & 1.427 & 1.063 & 0.937 & 1.096 & 1.181 & 1.081 \\
\hline CTI-25 & 3.663 & 1.502 & 1.119 & 0.986 & 1.154 & 1.244 & 1.138 \\
\hline CTI-26 & 6.777 & 2.778 & 2.071 & 1.824 & 2.135 & 2.301 & 2.104 \\
\hline CTI-27 & 6.777 & 2.778 & 2.071 & 1.824 & 2.135 & 2.301 & 2.104 \\
\hline CTI-28 & 7.692 & 3.154 & 2.351 & 2.071 & 2.423 & 2.612 & 2.389 \\
\hline CTI-29 & 3.846 & 1.577 & 1.175 & 1.036 & 1.212 & 1.306 & 1.194 \\
\hline CTI-30 & 3.846 & 1.577 & 1.175 & 1.036 & 1.212 & 1.306 & 1.194 \\
\hline CTI-31 & 5.861 & 2.403 & 1.791 & 1.578 & 1.846 & 1.990 & 1.820 \\
\hline CTI-32 & 6.044 & 2.478 & 1.847 & 1.627 & 1.904 & 2.052 & 1.877 \\
\hline CTI-33 & 4.029 & 1.652 & 1.231 & 1.085 & 1.269 & 1.368 & 1.251 \\
\hline CTI-34 & 4.029 & 1.652 & 1.231 & 1.085 & 1.269 & 1.368 & 1.251 \\
\hline CTI-35 & 4.212 & 1.727 & 1.287 & 1.134 & 1.327 & 1.430 & 1.308 \\
\hline CTI-36 & 4.212 & 1.727 & 1.287 & 1.134 & 1.327 & 1.430 & 1.308 \\
\hline CTI-37 & 4.212 & 1.727 & 1.287 & 1.134 & 1.327 & 1.430 & 1.308 \\
\hline CTI-38 & 4.396 & 1.802 & 1.343 & 1.183 & 1.385 & 1.492 & 1.365 \\
\hline CTI-39 & 4.396 & 1.802 & 1.343 & 1.183 & 1.385 & 1.492 & 1.365 \\
\hline CTI-40 & 4.579 & 1.877 & 1.399 & 1.233 & 1.442 & 1.555 & 1.422 \\
\hline CTI-41 & 4.579 & 1.877 & 1.399 & 1.233 & 1.442 & 1.555 & 1.422 \\
\hline CTI-42 & 4.579 & 1.877 & 1.399 & 1.233 & 1.442 & 1.555 & 1.422 \\
\hline CTI-43 & 2.747 & 1.126 & 0.839 & 0.740 & 0.865 & 0.933 & 0.853 \\
\hline CTI-44 & 4.762 & 1.952 & 1.455 & 1.282 & 1.500 & 1.617 & 1.479 \\
\hline CTI-45 & 5.128 & 2.102 & 1.567 & 1.381 & 1.615 & 1.741 & 1.593 \\
\hline CTI-46 & 5.128 & 2.102 & 1.567 & 1.381 & 1.615 & 1.741 & 1.593 \\
\hline CTI-47 & 5.311 & 2.177 & 1.623 & 1.430 & 1.673 & 1.803 & 1.649 \\
\hline CTI-48 & 5.311 & 2.177 & 1.623 & 1.430 & 1.673 & 1.803 & 1.649 \\
\hline CTI-49 & 5.311 & 2.177 & 1.623 & 1.430 & 1.673 & 1.803 & 1.649 \\
\hline CTI-50 & 5.678 & 2.328 & 1.735 & 1.529 & 1.788 & 1.928 & 1.763 \\
\hline
\end{tabular}


Table 3 (continued)

\begin{tabular}{llllllll}
\hline S. no. & 6 to 12 months & 6 to 11 years & 11 to 16 years & 16 to 18 years & 18 to 21 years & $>21$ years & $>65$ years \\
\hline CTI-51 & 5.678 & 2.328 & 1.735 & 1.529 & 1.788 & 1.928 & 1.763 \\
CTI-52 & 5.678 & 2.328 & 1.735 & 1.529 & 1.788 & 1.928 \\
CTI-53 & 5.678 & 2.328 & 1.735 & 1.529 & 1.788 & 1.928 \\
CTI-54 & 2.747 & 1.126 & 0.839 & 0.740 & 0.865 & 0.933 & 0.853 \\
\hline
\end{tabular}

5.11E-03, $1.95 \mathrm{E}-06$ to $2.58 \mathrm{E}-03$ and $2.24 \mathrm{E}-06$ to $2.09 \mathrm{E}-03$ with a mean of $1.53 \mathrm{E}-01,3.63 \mathrm{E}-03$ and $3.04 \mathrm{E}-03$ for 6-12 months, 6-11 years and 11-16 years and for $16-18$ years, $18-21$ years, $\geq 21$ years and $>65$ years differed from $4.06 \mathrm{E}-06$ to $1.92 \mathrm{E}-03,2.74 \mathrm{E}-03$ to $1.44 \mathrm{E}-02$, $2.38 \mathrm{E}-03$ to $1.25 \mathrm{E}-02$ and $2.30 \mathrm{E}-03$ to $9.01 \mathrm{E}-03$ with an average of $3.00 \mathrm{E}-03,4.08 \mathrm{E}-01,3.54 \mathrm{E}-01$ and $2.54 \mathrm{E}-01$, respectively. This suggests that dermal contact pathway is quite low than the ingestion pathway of contaminated water in the above-mentioned age groups. On other words ingestion pathway of contaminated water is the principal exposure pathway for non-carcinogenic risk in the hard rock terrain of the study region.

\section{Conclusions}

In this study, 54 groundwater samples were collected and analysed for various physicochemical parameters to understand the general geochemistry of groundwater and fluoride contamination and its health risk assessment in the hard rock terrain of Siddipet, India. The outcomes of the study can be summarized as follows:

- Groundwater of the study region is neutral-to-mildly alkaline nature. Sodium is the dominant cation, followed by calcium, magnesium and potassium. Bicarbonate is the abundant anion, followed by chloride, sulphate, nitrate and then fluoride, respectively. The spatial variation map of fluoride shows that larger than $3 \mathrm{mg} / \mathrm{L}$ fluoride concentration was noticed in the villages of Tudkapalli, Ponnala and Bakri Cheppll which are the southern part of the study area.

- The piper trilinear diagram (PTD) reveals that more than $70 \%$ of groundwater samples had alkaline earth metals exceeding alkali metals. The classification of the water types ranked as $\mathrm{Na}^{+}-\mathrm{Cl}^{-}, \mathrm{Ca}^{2+}-\mathrm{Mg}^{2+}-\mathrm{Cl}^{-}$and $\mathrm{Na}^{+}-\mathrm{HCO}_{3}{ }^{-}-\mathrm{Cl}^{-}$. Further, the groundwater chemistry of the study region is controlled by the mechanism of rock-water interactions/rock dominance process. $57.4 \%$ of groundwater samples are involved in the reverse ion exchange process and remaining are direct ion exchange-controlled groundwater chemistry in the study region.
- The assessment of non-carcinogenic risk showed that this incurred due to the intake of contaminated drinking water in the hard rock terrain of Siddipet. The $\mathrm{HQ}_{\text {in }}$ values ranged from 1.465 to 7.692 for age 6 to 12 months, while 0.601 to $3.154,0.448$ to $2.351,0.394$ to $2.071,0.462$ to $2.423,0.497$ to 2.612 , and 0.455 to 2.389 for age 6 to 11 years, 11 to 16 years, 16 to 18 years, 18 to 21 years, $>21$ years and $>65$ years, respectively. The results of $\mathrm{HQ}_{\mathrm{de}}$ show that the health risk ranged from $9.78 \mathrm{E}-04$ to $5.11 \mathrm{E}-03,1.95 \mathrm{E}-06$ to $2.58 \mathrm{E}-03$ and $2.24 \mathrm{E}-06$ to $2.09 \mathrm{E}-03$ for $6-12$ months, 6-11 years and $11-16$ years, while $4.06 \mathrm{E}-06$ to $1.92 \mathrm{E}-03,2.74 \mathrm{E}-03$ to $1.44 \mathrm{E}-02,2.38 \mathrm{E}-03$ to $1.25 \mathrm{E}-02$ and $2.30 \mathrm{E}-03$ to $9.01 \mathrm{E}-03$ for $11-16$ years and for 16-18 years, $18-21$ years, $\geq 21$ years and $>65$ years, respectively. The results showed that all samples have exceeded the acceptable limit of $\mathrm{HQ}=1$ for 6 to 12 months, posing this age group had a higher chronic hazard on the health risks. Therefore, the necessary steps to be taken to abolish this highly fluoride-contaminated groundwater and health risks in this study region. Furthermore, the obtained results of the study will be a scientific basis for groundwater management, and it will also be helpful to take necessary actions for providing safe and protect drinking water for the study region.

Acknowledgements This work was supported by the Department of Science and Technology (DST)—Science and Engineering Research Board (SERB) Government of India, New Delhi, under the Start-Up Research Grant Project (SR/FTP/ES-13/2013). The authors would like to thank the two anonymous reviewers for their helpful comments and suggestions helped us to improve the quality of the paper.

\section{Compliance with ethical standards}

Conflict of interest On behalf of both authors, the corresponding author states that there is no conflict of interest.

\section{References}

1. Emenike CP, Tenebe IT, Jarvis $P$ (2018) Fluoride contamination in groundwater sources in southwestern Nigeria: assessment using multivariate statistical approach and human health risk. Ecotoxicol Environ Saf 156:391-402 
2. Adimalla N (2018) Groundwater quality for drinking and irrigation purposes and potential health risks assessment: a case study from semi-arid region of south India. Expo Health. https ://doi.org/10.1007/s12403-018-0288-8

3. Shaji E, Viju BJ, Thambi DS (2007) High fluoride in ground waters of Palghat district, Kerala. Current Sci 92(2):240-246

4. Narsimha A, Sudarshan V (2018) Drinking water pollution with respective of fluoride in the semi-arid region of Basara, Nirmal district, Telangana state, India. Data Brief 16:752-757. https:// doi.org/10.1016/j.dib.2017.11.087

5. Apambire WB, Boyle DR, Michel FA (1997) Geochemistry, genesis, and health implications of fluoriferous groundwater in the upper regions of Ghana. Environ Geol 33(1):13-24. https://doi. org/10.1007/s0025

6. Ayoob S, Gupta AK (2006) Fluoride in drinking water: a review on the status and stress effects. Crit Rev Environ Sci Technol 36:433-487

7. Narsimha A, Sudarshan V (2017) Assessment of fluoride contamination in groundwater from Basara, Adilabad district, Telangana state, India. Appl Water Sci 7(6):2717-2725. https://doi. org/10.1007/s13201-016-0489-x

8. Subba Rao N, Marghade D, Dinakar A, Chandana I, Sunitha B, Ravindra B, Balaji T (2017) Geochemical characteristics and controlling factors of chemical composition of groundwater in a part of Guntur district, Andhra Pradesh, India. Environ Earth Sci 76:747. https://doi.org/10.1007/s12665-017-7093-8

9. Guo Q, Wang Y, Ma T, Ma R (2007) Geochemical processes controlling the elevated fluoride concentration in groundwaters of the Taiyuan basin, northern China. J Geochem Explor 93:1-12

10. Chen J, Wu H, Qian H, Gao Y (2017) Assessing nitrate and fluoride contaminants in drinking water and their health risk of rural residents living in a semiarid region of northwest China. Expo Health 9(3):183-195. https://doi.org/10.1007/s1240 3-016-0231-9

11. Wu J, Li P, Qian H (2015) Hydrochemical characterization of drinking groundwater with special reference to fluoride in an arid area of China and the control of aquifer leakage on its concentrations. Environ Earth Sci 73(12):8575-8588. https://doi. org/10.1007/s12665-015-4018-2

12. Oruc N (2003) Problems of high fluoride waters in Turkey (hydrogeology and health aspects). The short course on medical geology-health and environment. Canberra, Australia

13. Kim K, Jeong YG (2005) Factors influencing natural occurrence of fluoride-rich round waters: a case study in the southeastern part of the Korean Peninsula. Chemosphere 58:1399-1408

14. Carrillo-Rivera JJ, Cardona A, Edmunds WM (2002) Use of abstraction regime and knowledge of hydrogeological conditions to control high-fluoride concentration in abstracted groundwater: San Luis Potosı basin. Mex J Hydrogeol 261:24-47

15. Adimalla N, Li P, Venkatayogi S (2018) Hydrogeochemical evaluation of groundwater quality for drinking and irrigation purposes and integrated interpretation with water quality index studies. Environ Process 5(2):363-383. https://doi.org/10.1007/s4071 0-018-0297-4

16. Adimalla N, Li P, Qian H (2018) Evaluation of groundwater contamination for fluoride and nitrate in semi-arid region of Nirmal province, south India: a special emphasis on human health risk assessment (HHRA). Hum Ecol Risk Assess Int J. https://doi. org/10.1080/10807039.2018.1460579

17. Adimalla N, Vasa SK, Li P (2018) Evaluation of groundwater quality, Peddavagu in Central Telangana (PCT), south India: an insight of controlling factors of fluoride enrichment. Model Earth Syst Environ 4(2):841-852. https://doi.org/10.1007/s4080 8-018-0443-z

18. Adimalla N, Li P (2018) Occurrence, health risks, and geochemical mechanisms of fluoride and nitrate in groundwater of the rock-dominant semi-arid region, Telangana state, India. Hum Ecol Risk Assess Int J. https://doi.org/10.1080/10807 039.2018.1480353

19. Narsimha A (2018) Elevated fluoride concentration levels in rural villages of Siddipet, Telangana state, south India. Data Brief 16:693-699. https://doi.org/10.1016/j.dib.2017.11.088

20. Adimalla N (2019) Spatial distribution, exposure, and potential health risk assessment from nitrate in drinking water from semiarid region of south India. Hum Ecol Risk Assess Int J. https://doi. org/10.1080/10807039.2018.1508329

21. Deepu TR, Shaji E (2011) Fluoride contamination in groundwater resources of Chittur block, Palghat district, Kerala, India-a health risk. In: Disaster, risk and vulnerability conference, pp 12-14

22. Raj D, Shaji E (2017) Fluoride contamination in groundwater resources of Alleppey, southern India. Geosci Front 8(1):117-124

23. Gizaw B (1996) The origin of high bicarbonate and fluoride concentration in waters of the main Ethiopian Rift Valley, East African Rift System. J Afr Earth Sci 22:391-402

24. Smith DA, Harris HA, Kirk R (1953) Fluorosis in the Butan, Sudan. J Trop Med Hyg 8:57-58

25. Ocherse T (1953) Chronic endemic fluorosis in Kenya, east Africa. Br Dent J 95:57-61

26. Grech $P$ (1966) Fluorosis in young persons: further survey in northern Tanganyika, Tanzania. Brit J Radiol 39:760-764

27. Tekle-Haimanot R, Fekadu A, Bushra B (1987) Endemic fluorosis in the Ethiopian Rift Valley. Trop Geogr Med 39:209-217

28. Fuhong R, Shuqin J (1988) Distribution and formation of highfluorine groundwater in China. Environ Geol Water Sci 12(1):3-10

29. Ando M, Tadano M, Yamamoto S, Tamura K, Asanuma S, Watanabe $T$ (2001) Health effects of fluoride pollution caused by coal burning. Sci Total Environ 271:107-116

30. EPA (2010) Fluoride: exposure and relative source contribution analysis. United States Environmental Protection Agency, Washington, DC. 820-R-10-015

31. Craig L, Lutz A, Berry KA, Yang W (2015) Recommendations for fluoride limits in drinking water based on estimated daily fluoride intake in the Upper East Region, Ghana. Sci Total Environ 532:127-137. https://doi.org/10.1016/j.scitotenv.2015.05.126

32. Adimalla N, Venkatayogi S (2018) Geochemical characterization and evaluation of groundwater suitability for domestic and agricultural utility in semi-arid region of Basara, Telangana state, south India. Appl Water Sci 8:44. https://doi.org/10.1007/s1320 1-018-0682-1

33. Hem JD (1985) The study and interpretation of the chemical characteristics of natural water, 3rd edn. U.S. Geological Survey Water-Supply, Paper 2254

34. Saxena VK, Ahmed S (2003) Inferring the chemical parameters for the dissolution of fluoride in ground waters. Environ Geol 43:731-736

35. Edmunds WM, Smedley PL (2005) Fluoride in natural waters. In: Selinus O (ed) Essentials of medical geology. Elsevier Academic Press, Burlington, pp 301-329

36. Chae GT, Yun ST, Mayer B, Kim KH, Kim SY, Kwon JS et al (2007) Fluorine geochemistry in bedrock groundwater of South Korea. Sci Total Environ 385(1-3):272-283. https://doi.org/10.1016/j. scitotenv.2007.06.038

37. Narsimha A, Rajitha S (2018) Spatial distribution and seasonal variation in fluoride enrichment in groundwater and its associated human health risk assessment in Telangana state, south India. Hum Ecol Risk Assess Int J 24(8):2119-2132. https://doi. org/10.1080/10807039.2018.1438176

38. Adimalla N, Venkatayogi S (2017) Mechanism of fluoride enrichment in groundwater of hard rock aquifers in Medak, Telangana state, south India. Environ Earth Sci 76:45. https://doi. org/10.1007/s12665-016-6362-2 
39. Narsimha A, Sudarshan V (2017) Contamination of fluoride in groundwater and its effect on human health: a case study in hard rock aquifers of Siddipet, Telangana state, India. Appl Water Sci 7(5):2501-2512. https://doi.org/10.1007/s13201-016-0441-0

40. Adimalla N, Wu J (2019) Groundwater quality and associated health risks in a semi-arid region of south India: implication to sustainable groundwater management. Hum Ecol Risk Assess Int J. https://doi.org/10.1080/10807039.2018.1546550

41. CGWB (2013) Groundwater brochure Medak district, Andhra Pradesh. Central Groundwater Water Board (CGWB), Ministry of Water Resources, Government of India

42. APHA (1995) Standard methods for estimation of water and waste water, 19th edn. American Public Health Association, Washington, DC

43. Domenico PA, Schwartz FW (1990) Physical and chemical hydrogeology. Wiley, New York

44. US EPA (2011) Exposure factors handbook: 2011 edition, 2011th edn. United States Environmental Protection Agency, Washington, DC EPA/600/R-090/052F

45. US EPA (1989) Risk assessment guidance for superfund volume I human health evaluation manual (part A). United States Environmental Protection Agency, Washington, DC EPA/540/1-89/002

46. WHO (2011) Guidelines for drinking-water quality, 4th edn. WHO, Geneva. http://www.who.int/water_sanitation_health/ publications/dwq_guidelines/en/\#

47. Edmunds WM, Smedley PL (2013) Fluoride in natural waters. Essentials of medical geology. Springer, Dordrecht, pp 311-336

48. Gibbs RJ (1970) Mechanisms controlling world water chemistry. Science 170:795-840. https://doi.org/10.1126/scien ce.170.3962.1088
49. Stallard RF, Edmond JM (1983) Geochemistry of the Amazon, the influence of geology and weathering environment on the dissolved load. J Geophys Res 88:9671-9688

50. Piper AM (1944) A graphical procedure in the geochemical interpretation of water analysis. Trans Am Geophys Union 25:914-928

51. Dehbandi R, Moore F, Keshavarzi B (2018) Geochemical sources, hydrogeochemical behavior, and health risk assessment of fluoride in an endemic fluorosis area, central Iran. Chemosphere 193:763-776. https://doi.org/10.1016/j.chemospher e.2017.11.021

52. Langmuir D, Hall P, Drever J (1997) Aqueous environmental geochemistry. Prentice Hall, New Jersey

53. Rafique T, Naseem S, Ozsvath D, Hussain R, Bhanger MI, Usmani TH (2015) Geochemical controls of high fluoride groundwater in Umarkot sub-district, Thar desert, Pakistan. Sci Total Environ 530:271-278

54. Schoeller H (1967) Geochemistry of groundwater. An international guide for research and practice, chap. 15. UNESCO, Paris, pp 1-18

Publisher's Note Springer Nature remains neutral with regard to jurisdictional claims in published maps and institutional affiliations. 